\title{
Effects of experience and commercialisation on survival in Himalayan mountaineering: retrospective cohort study
}

\author{
(c) $(1) \Theta$ OPEN ACCESS
}

\author{
John L Westhoff staff physician ${ }^{1}$, Thomas D Koepsell professor ${ }^{2}$, Christopher T Littell program \\ director of residency in public health and general preventive medicine ${ }^{1}$
}

'Department of Preventive Medicine, Madigan Healthcare System, Tacoma, WA 98431-1100, USA; ${ }^{2}$ Department of Epidemiology, University of Washington, Seattle, WA

\begin{abstract}
Objectives To determine whether previous Himalayan experience is associated with a decreased risk of climbing death, and whether mountaineers participating in commercial expeditions differ in their risk of death relative to those participating in traditional climbs.

Design Retrospective cohort study.

Setting Expeditions in the Nepalese Himalayan peaks, from 1 January 1970 to the spring climbing season in 2010.

Participants 23995 non-porters venturing above base camp on 39038 climbs, 23295 on 8000 m peaks.

Outcome Death.

Results After controlling for use of standard route, peak, age, season, sex, summit success, and year of expedition, increased Himalayan experience was not associated with a change in the odds of death (odds ratio $1.00,95 \%$ confidence interval 0.96 to $1.05, \mathrm{P}=0.904$ ). Participation in a commercial climb was associated with a $37 \%$ lower odds of death relative to a traditional venture, although not significantly $(0.63,0.37$ to $1.09, P=0.100)$. Choice of peak was clearly associated with altered odds of death (omnibus $\mathrm{P}<0.001$ ); year of expedition was associated with a significant trend toward reduced odds of death $(0.98,0.96$ to 0.99 , $\mathrm{P}=0.011$ ).

Conclusions No net survival benefit is associated with increased Himalayan experience or participation in a traditional (versus commercial) venture. The incremental decrease in risk associated with calendar year suggests that cumulative, collective knowledge and general innovation are more important than individual experience in improving the odds of survival.
\end{abstract}

\section{Introduction}

Climbing mountains can be extremely dangerous. ${ }^{12}$ Most victims of mountaineering accidents are relatively young, commonly in their $30 \mathrm{~s},{ }^{3-5}$ and misadventures are often associated with costly search and rescue operations. ${ }^{6-8}$ These factors, and the increasing popularity of the sport, make mountaineering mishaps a growing public health concern for local municipalities and responsible government agencies.

Although comparisons across sports are difficult owing to large differences in time at risk, the per-participant mortality rate for mountaineering in general has been estimated as roughly three times higher than parachuting or hang gliding and 300 times higher than American football. ${ }^{9}$ A comparison of participant mortality in England and Wales found that mountaineering was by far the most deadly of any athletic endeavour studied, despite the relatively low altitude of the British high country. ${ }^{10}$ The extraordinary risk borne by avid climbers was highlighted by a small prospective cohort study of New Zealand based mountaineers; at four year follow-up, $8.2 \%$ of the participants had died in mountaineering accidents, ${ }^{11}$ corresponding to a death rate (per person year) five times that of military personnel deployed to coalition occupied Iraq in 2003-06. ${ }^{12}$

Although it stands to reason that mountaineers could benefit from their own experience and the collective experience of others, the nature and extent of that benefit is unclear. Boyce and Bischack found that the total number of previous expeditions to a particular mountain peak was associated with a significant decrease in the incidence of frostbite and altitude sickness. They attributed this result to the benefits of cumulative, industry wide experience that is made available to climbers via media, guides, and personal communications among participants. But they also noted that "learning by doing" (gaining knowledge from personal experience on previous expeditions) provided no advantage in terms of reducing the risk of death. ${ }^{13}$

The notion that experience does not bestow a net survival benefit is contrary to the belief of some mountaineers. In his autobiography, No Shortcuts to the Top, American high altitude climber Ed Viesturs recounted a "provocative exchange" with a journalist who confronted him with statistical evidence of the 
high risks associated with mountaineering. Viesturs told the journalist that the statistics "[didn't] apply to me," rationalising that the mortality rate in question "included all kinds of poorly trained or inexperienced climbers on their first expeditions to an 8,000er." He then explained his personal view that the risk of death decreases with successive climbs (that is, personal experience is protective):

"Each expedition is separate from the previous one. If I learn something from a previous climb, and become a better mountaineer-smarter, faster, stronger, more efficient - then the next climb will be safer. The risk actually goes down!"14

Since the 1990s, the Himalayas have seen an explosion in the commercialisation of high altitude mountaineering. For a considerable fee, professional guide services will provide the support necessary to get relatively inexperienced mountaineers to the top of the world's highest peaks. High profile deaths in commercial expeditions on Mount Everest in 1996 and 2006 garnered considerable media attention, and there have been concerns that imprudent commercialisation has increased the probability of accidents by putting ever increasing numbers of novices on the mountain. Tumbat and Belk, reporting the thoughts of a Mount Everest guide, provide an illustration of this point of view:

\begin{abstract}
"If you could put another route up Everest and say this is the tourist route, and you say you guys go along there and take as long as you want and stop and have chocolate bars and stop and have cups of coffee, great, but it isn't like that. There's one route up there, we've all got to use it, and we've all got to be considerate about one another, and lots of people attribute many deaths to the incompetence of people blocking up the route." 15
\end{abstract}

Even so, an overall trend toward increasing success rates in summiting Mount Everest without an associated rise in death supports the contention that professionally guided climbs could actually improve safety overall. With more novice climbers reaching $8000 \mathrm{~m}$ summits under the watchful eye of professional guides, Huey and Salisbury have argued that any "decline in average skill and experience has been more than balanced by improved equipment and logistics, better weather forecasting, greater cumulative knowledge of the routes, and enhanced experience of ... porters and leaders." ${ }^{.16}$ A formal analysis of the relative risk of death borne by commercial expeditions relative to non-commercial expeditions has not been done.

The primary aim of this study was to determine whether experience with previous Himalayan expeditions was associated with a decreased risk of death on subsequent climbs. We also aimed to determine the risk of death borne by mountaineers on commercial ventures compared with those embarking on traditional, non-commercial expeditions.

\section{Methods}

\section{Study design and setting}

This study used a unique data source created by Richard Salisbury and published by the American Alpine Club as the Himalayan Database. Originally derived from the archives of Elizabeth Hawley, a journalist and longtime resident of Kathmandu, the database is the definitive record of mountaineering in the Nepalese Himalayas. ${ }^{17}{ }^{18}$ We did a retrospective analysis of mortality in a cohort of mountaineers whose climbs were recorded in the database. The primary exposures of interest included previous Himalayan experience and participation in a commercial expedition.

We limited analysis to expeditions from 1 January 1970 to the spring climbing season of 2010. The period of 1970 to 1989 was a time of transition between the previous exploratory and expeditionary eras and the present commercial period of Himalayan mountaineering, which began in earnest around 1990. ${ }^{19}$

\section{Study participants}

We found 39038 of 52161 available observations that met criteria for inclusion. Each observation represented the effort of a person on one expedition - that is, a climb rather than a climber. Mountaineers were represented by the requisite number of observations when they participated in multiple climbs. Similarly, the expedition of a climbing party was represented by as many observations as there were members in the group - the observations referring to the individual effort rather than the collective effort. We excluded observations if they occurred before 1970, if climbers did not travel above base camp, or if climbers functioned as a high altitude porter.

Of climbs occurring before the transitional era of modern mountaineering began (that is, 1970), 2259 were excluded. Expeditions before this time were less frequent and were associated with equipment and techniques notably disparate from those used by modern mountaineers. ${ }^{19} \mathrm{We}$ also excluded 3812 additional observations because they did not travel higher than base camp. Another 7052 climbs by high altitude porters were excluded to eliminate any confounding inherent in their unique role. We defined a porter as any person identified in the database as a porter or sirdar (that is, head sherpa), hired with explicit status as a cook or assistant, or hired for support or ladder removal. The remaining 39038 observations meeting inclusion criteria for the study represented the efforts of 23995 unique climbers.

\section{Data}

Since 1963, Elizabeth Hawley or her assistants have interviewed almost every expedition to Nepal, both before and after climbing. Information collected in these interviews form the bulk of the data contained in the Himalayan Database. In addition, the database is supplemented by information collected from books, journals, and personal correspondence to complete the historical record as far back as 1905. Updates are published online twice a year. The dataset used in this analysis was updated to include the spring 2010 climbing season. First published in 2004, the Himalayan Database has been the source of data for several scientific publications. ${ }^{216}{ }^{19-21}$ We did analyses using Stata (release 11, 2009; StataCorp).

\section{Variables}

Exposures of interest included Himalayan mountaineering experience and commercial status. Expedition number was used as a proxy for Himalayan mountaineering experience and was defined by the sequence of a climb associated with a specific person-for example, a climber's first effort was " 1 " and the second effort was "2" and so on. A climb was considered "commercial" if identified as such in the database. The outcome of interest was death.

Potential confounders included age, sex, season of climb, altitude, peak and route selection, summit success, and year of expedition. Most climbs in the Himalayas are conducted during relatively short climbing seasons in the spring and autumn. Elite alpinists occasionally attempt off season ascents (for example, 
monsoon), which are noteworthy in view of the increased degree of difficulty associated with more austere conditions. As a potential confounder with few categories, season could be easily controlled for.

The peak chosen by a person represents a potential confounder because mountains differ considerably in their mortality profiles and peaks perceived as safer tend to attract more less

experienced climbers. Of course, not all expeditions to a specific peak ascend by the same route, and routes differ greatly in their success and death rates. ${ }^{16}$ The protean variations of routes made it impractical to control for route selection directly.

Alternatively, we applied a binary "standard route" variable to indicate when the predominant route used by an expedition was previously established and generally accepted as the normal ascent. We controlled for the potentially confounding effect of altitude by limiting multivariate analysis to climbs on peaks of similar altitude (that is, $>8000 \mathrm{~m}$ ).

We regarded summit success (that is, whether a climber reaches the summit on a particular climb) as both an intermediate outcome and a potential confounder, because it is associated with a mountaineer's experience and decision making process en route, and influences his subsequent risk of death. Descent is generally considered more dangerous than ascent. Since commercial expeditions have tended to occur more recently, we included year of expedition as a covariate to control for potential confounding due to an overall secular trend of decreasing percentages of deaths per climb.

\section{Statistical methods}

We used logistic regression in a framework of generalised estimating equations to estimate odds ratios of death.

Generalised estimating equations yield valid estimates of odds ratios for non-independent observations and have the advantage of being robust to mis-specification of the correlation structure. ${ }^{22}$

Himalayan Database data are non-independent, both longitudinally (that is, multiple observations per person) and by virtue of nesting within expeditions. Miglioretti and Heagerty described a method for adjusting for correlation within such non-nested clusters using standard software. ${ }^{23}{ }^{24}$ Applying this method, we constructed a summary covariance matrix from the output of two, otherwise identical, population averaged models (using different nesting variables - that is, "expedition id" and "individual id"). We obtained a vector of estimated variances from the resulting matrix, from which we calculated valid standard error estimates for constructing confidence intervals and conducting statistical tests. We generated $\mathrm{P}$ values via a $\chi^{2}$ statistic derived from an omnibus Wald test applied to each variable in toto. Results were considered significant for $\mathrm{P} \leq 0.05$.

We used Kaplan-Meier methodology to generate an estimate of cumulative mortality as a function of the number of expeditions. We chose the number of expeditions rather than calendar time as the relevant index. The resulting plot can be interpreted as an estimate of the cumulative risk of death for a hypothetical aggregate of a Himalayan climbing career.

\section{Results}

\section{Descriptive analysis}

Table $1 \Downarrow$ details basic demographic characteristics of the study cohort. Climbers were predominantly male (21 555 (89.8\%) of 23 995), with a large proportion in their thirties (8945 (37.3\%)). The average climbing age was 32 years. Most mountaineers were represented in database by their debut climb only (16976 (70.7\%)), with $15586(39.9 \%)$ of 39038 total climbs undertaken by those with previous experience on a constituent peak. An additional $48.0 \%$ more climbs were attempted on 8000 m peaks than on summits of lower altitude during the study period (23 $295 v 15743$ ), a pattern which was also seen for debut climbs, but to a lesser extent (11.8\%; $12365 v 11055)$.

Table $2 \Downarrow$ highlights differences between traditional and commercial expeditions. Mountaineers participating in traditional expeditions were on average five years younger and slightly less experienced ( $2.2 v 2.6$ average climbs) than those on commercial expeditions. Predictably, commercial climbers were more likely to ascend by a standard route $(6392(80.4 \%)$ of $7955 v 15290(49.2 \%)$ of 31083$)$ and were less likely to make an off season attempt (that is, during the summer or winter; $136(1.7 \%) v 1784(5.7 \%))$. We also saw a distinct difference in the choice of peak, with $4386(86.6 \%)$ of 5063 commercial climbs over $8000 \mathrm{~m}$ occurring on just two peaks, Mount Everest and Cho Oyu (the second of which is generally considered the easiest peak over $8000 \mathrm{~m}$ to climb). These two mountains also made up the bulk of traditional climbs compared with commercial climbs, but to a lesser extent (10 636 (58.3\%) of 18 232), with an increased traffic dedicated to notoriously dangerous peaks such as Annapurna I (1144 (6.3\%) v 55 (1.1\%)). Commercial climbers were more likely than traditional climbers to summit (3534 (44.4\%) v 8712 (28.0\%)) and less likely to die on an expedition $(55(0.7 \%) v 524(1.7 \%))$.

The most common mechanism of death among mountaineers of either status was falling (216 (41.2\%) of 524 traditional climbs $v 29(52.7 \%)$ of 55 commercial climbs; table 2). However, the second most common mechanism of death was exposure in commercial climbs (eight $(14.5 \%)$ ) and avalanche in traditional climbs $(162(30.9 \%))$. Table $3 \Downarrow$ provides further detail on differences in the patterns of death between commercial and non-commercial ventures. People on traditional climbs were most likely to die during the route preparation phase of a climb (244 (46.6\%)), especially for deaths from avalanches. Commercial climbers were most likely to die during their summit bid, with a large majority of summit related deaths occurring on descent rather than ascent (41 (74.5\%) $v$ two $(3.6 \%)$ ). By contrast, $171(32.6 \%)$ traditional climbers died on descent and $64(12.2 \%)$ on ascent. The increased likelihood of death on ascent for traditional climbs than for commercial climbs was largely due to a raised risk of falling while ascending ( 38 $(7.3 \%) v 0$ ), which probably reflected the tendency of these mountaineers to select non-standard routes on more dangerous objectives.

Table $4 \Downarrow$ shows the trends associated with increased climber experience in the Nepalese Himalayas. Debut mountaineers were much more likely to climb Cho Oyu than those on their second to fourth expedition (3813 (30.8\%) of 12365 debut climbs on peaks $>8000 \mathrm{~m} v 1404(18.2 \%)$ of 7735 second to fourth climbs), a trend that was reversed for Mount Everest $(4468(36.1 \%) v 3510(45.4 \%))$. The ratio of traditional to commercial climbers remained constant (roughly split 80:20) until they reached beyond their 10th climb, in which 353 (28.8\%) of 1225 climbs were part of a commercial expedition, presumably a reflection of the disproportionate experience of professional guides. More experienced mountaineers were more likely to have success in reaching the summit (trend increase in success rate with experience, from $26.7 \%$ for debut climbs to $50.2 \%$ for 10 th climbs and beyond; table 4). Experience was also associated with an increased likelihood of using a standard route (trend increase with experience, from 12212 (52.1\%) for debut climbers to $865(70.6 \%)$ for the most experienced climbers). We did not see a clear association between experience and overall percentage of death $(1.5 \%)$. 
Table $5 \Downarrow$ illustrates temporal trends by decade, highlighting both a demographic shift (increasing percentages of women and climbers aged $>40$ years) and a dramatic change in outcomes. The likelihood of successfully reaching the summit increased from $21.4 \%$ (1833 of 8574 attempts) in the 1980 s to $39.8 \%$ (6096 of 15 320) since 2000. The likelihood of death decreased from $3.0 \%$ (91 deaths in 3080 climbs) in the 1970 s to $0.9 \%$ (134) since 2000. Traditional climbs made up the vast majority of observations over the entire 40 year period of the study (30 588 (80\%) of 38243 ). However, despite comprising less than $5 \%$ of all observations in the 1970s and 1980s, commercial climbs accounted for almost a third of all climbs in the 21st century. Figure $1 \Downarrow$ shows the annual increase in climbs in the region and the trend toward an increasing proportion of commercial climbs.

\section{Multivariate and survival analyses}

Odds ratios of death were estimated via a model of generalised estimating equations that incorporated Nepalese mountaineering experience (number of database expedition for each climber), commercial status, use of standard route, peak, age, season, sex, summit success, and year of expedition as covariates. Although we implicitly preserved experience on peaks lower than 8000 $m$ in the experience variable, we excluded 15743 of the 39038 available observations on these lower peaks from the analysis, to accommodate the inclusion of peak as a covariate. The remaining 23295 observations represented all non-porter climbs on eight of the world's 14 peaks over $8000 \mathrm{~m}$ during the study period (table $6 \Downarrow$ ).

The primary aim of this study was to characterise the association between Himalayan mountaineering experience and likelihood of death. Table $7 \Downarrow$ summarises unadjusted mortality by climb characteristics. After controlling for other factors, increased experience (that is, a unit increase in expedition number) was not associated with any change in the odds of death (odds ratio $1.00,95 \%$ confidence interval 0.96 to $1.05, \mathrm{P}=0.904$ ). In relation to the study's secondary aim, participation in a commercial climb was not significantly associated with the odds of death $(0.63,0.37$ to $1.09, \mathrm{P}=0.100)$. The only covariates that were significantly associated with odds of death were peak (table 6 , omnibus $\mathrm{P}<0.001$ ), summit success (odds ratio $1.50,95 \%$ confidence interval 1.03 to $2.19, \mathrm{P}=0.036$ ), and year of expedition, with a significant trend toward reduced odds of death with every unit change of year $(0.98,0.96$ to 0.99 , $\mathrm{P}=0.011$ ). Use of a standard route, age, season, and sex were not significantly associated with odds of death.

Figure $2 \Downarrow$ shows results of the survival analysis. An estimate of cumulative mortality using Kaplan-Meier methodology yielded an essentially linear association (10\% mortality after seven expeditions, $20 \%$ after 15 expeditions).

\section{Discussion}

Results of our multivariate analysis and the essentially linear Kaplan-Meier mortality curve suggest that no net survival benefit is associated with increased Himalayan experience. A veteran of many climbs was, on average, no more or no less likely to die on a climb than a mountaineer on a first expedition to the region. This result is somewhat counterintuitive, since experience suggests and research has confirmed that in other areas of human endeavour, experience is associated with increased safety (for example, new drivers are known to have higher rates of automobile accidents than experienced drivers). A learning effect for survival could have been outweighed or undone by other factors, such as the choice of objectives of progressively increasing difficulty, both individually and collectively.

After adjusting for previous Nepalese experience, commercial status, use of a standard route, age, season, and sex, we found that only choice of peak, summit success, and the year of ascent had a significant impact on the odds of death. The suggestion that peaks differ in their degree of danger will not be controversial among mountaineers. Similarly, the increased risk of death associated with summit success is intuitive in view of the amplified danger, increased fatigue, and prolonged exposure time associated with attaining the highest point—as well as the potential for "summit fever," the notoriously bad judgment associated with summiting at any cost. The incremental decrease in odds of death for later expeditions, as shown by the significant risk reduction associated with calendar year, can be attributed to innovations not otherwise accounted for in the model. Improved logistics, training, technical equipment, acclimatisation strategies, weather forecasting, and other advancements are likely to manifest in this covariate. These improvements can be regarded as the products of collective experience, suggesting that communal knowledge and experience are more important than individual experience in providing an overall survival advantage.

Although the commercialisation of Himalayan mountaineering has received a great deal of negative attention, this analysis suggests that at least some of that criticism is undeserved. In this study, participation in a commercial expedition was associated with a potentially important decrease of $37 \%$ in the odds of death, though the confidence interval was too wide to exclude chance as an explanation.

\section{Strengths and limitations}

Near perfect capture of the entire population of climbers on constituent peaks was a strength that was inherent in the Himalayan Database. The logistical difficulties associated with mounting an expedition to the region, the requirement for most mountaineers to pass through Kathmandu, and the universal desire to have one's efforts documented in the Nepalese "database of record" decreased the likelihood that relevant climbs would go undocumented.

The designation of a climb as "commercial" by the originators of the Himalayan Database was taken at face value; thus, the subjectivity associated with such labelling of an expedition was a weakness. Although many expeditions are clearly for profit ventures (professionals paid to guide clients), the relationship between the members of modern expeditions can sometimes be ambiguous and be a potential source of misclassification. In addition, we made no distinction between clients and guides-these are subgroups that could differ in important ways from the general mountaineering population.

Another limitation was the need for using the number of Nepalese expeditions as a proxy for high altitude mountaineering experience. Mountaineering experience gained on external peaks was not reflected in the dataset. The database does not account for six of the world's 14 peaks over $8000 \mathrm{~m}$, and experience on peaks greater than $7000 \mathrm{~m}$ can be gained in several mountain ranges outside Nepal.

A potential bias in our study was the possibility that climbers who make at least one captured climb could subsequently die on a peak not included in the Himalayan Database. Climbers who venture (and return) to the Nepalese Himalayas undoubtedly represent a biased population - they have not been killed or seriously injured climbing elsewhere in the world and have a shown an aptitude for the vocation (or avocation as the case 
may be). This type of potential bias informs the generalisability of results to other populations of mountaineers such as those who climb only in the relatively low altitude peaks of Europe and North America. However, this weakness is irrelevant to the central aim of this study, in which the benefit of such selection, reflected in the number of Nepalese expeditions, was the question of primary interest.

The results and conclusions of this investigation could be safely generalisable to climbs in other central Asian ranges of similar altitude, such as the Hindu Kush and Karakorum. Whether these results apply to settings at lower altitude is a subject for future research. These findings do not apply to high altitude porters, who were excluded from the analysis. These results apply only to the cohort of climbers in aggregate and do not estimate risk for any subgroup not explicitly referred to in the analysis.

\section{Future research}

Although we did not find a survival advantage associated with experience, it is not difficult to imagine that a subset of climbers with special motivation to mitigate risk rather than push personal limits (for example, with hired sherpa and professional guides) might derive a net survival benefit associated with experience. A natural extension of this research would be to analyse these groups for evidence of a learning effect that might not be clearly shown in the general climbing population, particularly among guides and porters who have specialised in a particular peak or route.

The findings of this study open the door for consideration of commercialisation as a constructive innovation associated with positive outcomes, although further investigation is needed into the nature and wider implications of this growing trend. Such research should include an examination of variables not addressed in the present study, such as guide or client status, expedition leaders' experiences of the same peak, the density of climbers on a particular route, and other variables that differ between commercial operators (for example, sherpa to client ratio or the amount and use of supplemental oxygen).

We thank Elizabeth Hawley, whose life's work is distilled in the Himalayan Database; Richard Salisbury, whose efforts to convert Hawley's archives into an electronic database made this project possible, and for providing a customised modification of the Himal programme that allowed the inclusion of the standard route variable in this analysis; and Raymond Huey, for his recommendations on the study design and feedback on the manuscript.

This manuscript describes a systematic analysis of data archived in the Himalayan Database. The authors have obtained permission via written correspondence with Richard Salisbury (database author and administrator) and the American Alpine Club (publisher) to analyse the data for the purposes of this study. We have agreed that any publication resulting from the project will give due credit to "The Himalayan Database copyright 2004 by Richard Salisbury and Elizabeth Hawley."

Contributors: JLW conceived the study, carried out the analysis, drafted the original manuscript, and is the study guarantor. TDK guided the epidemiological methodology of the study, and CTL provided direction on design and conception of the project. All authors iteratively and collaboratively revised the manuscript and subsequently approved the final text.
Funding: No specific funding was received for this research.

Competing interests: All authors have completed the Unified Competing Interest form at www.icmje.org/coi_disclosure.pdf (available on request from the corresponding author) and declare: no support from any organisation for the submitted work; no financial relationships with any organisations that might have an interest in the submitted work in the previous 3 years; no other relationships or activities that could appear to have influenced the submitted work.

Ethical approval: The Human Subjects Division of the University of Washington reviewed the protocol associated with this research and determined that it does not constitute "human subjects research" and therefore does not require review by the institutional review board (exemption no 39319). A copy of the letter of exemption is available from JLW on request.

Data sharing: Statistical code available from JLW; data available from publisher via www.himalayandatabase.com.

Huey RB, Eguskitza X. Supplemental oxygen and mountaineer death rates on Everest and K2. JAMA 2000;284:181.

2 Firth PG, Zheng H, Windsor JS, Sutherland Al, Imray CH, Moore GW, et al. Mortality on Mount Everest, 1921-2006: descriptive study. BMJ 2008;337:a2654.

3 Weinbruch S, Nordby KC. Fatal accidents among elite mountaineers: a historical perspective from the European Alps. High Alt Med Biol 2010;11:147-51.

4 Lattimore C. Mountaineering emergencies on Denali. J Wilderness Med 1993;4:358-62. 5 Christensen ED, Lacsina EQ. Mountaineering fatalities on Mount Rainier, Washington, 1977-1997: autopsy and investigative findings. Am J Forensic Med Pathol 1999;20:173-9.

6 Heggie TW, Heggie TM. Search and rescue trends and the emergency medical service workload in Utah's National Parks. Wilderness Environ Med 2008:19:164-71.

7 Heggie TW, Amundson ME. Dead men walking: search and rescue in US National Parks. Wilderness Environ Med 2009;20:244-9.

8 Heggie TW. Search and rescue in Alaska's national parks. Travel Med Infect Dis 2008;6:355-61.

9 Windsor JS, Firth PG, Grocott MP, Rodway GW, Montgomery HE. Mountain mortality: a review of deaths that occur during recreational activities in the mountains. Postgrad Med J 2009;85:316-21.

10 Avery JG, Harper P, Ackroyd S. Do we pay too dearly for our sport and leisure activities? An investigation into fatalities as a result of sporting and leisure activities in England and Wales, 1982-1988. Public Health 1990;104:417-23.

11 Monasterio ME. Accident and fatality characteristics in a population of mountain climbers in New Zealand. N Z Med J 2005;118:U1249.

12 Preston SH, Buzzell E. Service in Iraq: just how risky? 2006. www.washingtonpost.com wp-dyn/content/article/2006/08/25/AR2006082500940_pf.html.

13 Boyce JR, Bischak DP. Learning by doing, knowledge spillovers, and technological and organizational change in high-altitude mountaineering. J Sports Econ 2010;11:496-532.

14 Viesturs E, Roberts D. No shortcuts to the top: climbing the world's 14 highest peaks. 1st ed. Broadway Books, 2006.

15 Tumbat G, Belk R. Marketplace tensions in extraordinary experiences. J Consumer Res 2011;38:42-61.

16 Huey RB, Salisbury R. Success and death on Mount Everest: how the main routes and seasons compare. Am Alpine J 2003;2:10.

17 Hansen E. The high priestess of posterity. Outside Magazine, April 2011:46-53.

18 O'Neil D. The one who counts. Rock and Ice Magazine, September 2010:42-76

19 Salisbury R, Hawley E. The Himalaya by numbers: a statistical analysis of mountaineering in the Nepal Himalaya. Vajra Publications, 2011.

20 Huey RB, Salisbury R, Wang J-L, Mao M. Effects of age and gender on success and death of mountaineers on Mount Everest. Biol Lett 2007;3:498-500.

21 Huey RB, Eguskitza X. Limits to human performance: elevated risks on high mountains. $J$ Exp Biol 2001;204:3115-9.

22 Hanley JA, Negassa A, Edwardes MD, Forrester JE. Statistical analysis of correlated data using generalized estimating equations: an orientation. Am J Epidemiol 2003;157:364-75.

23 Miglioretti DL, Heagerty PJ. Marginal modeling of multilevel binary data with time-varying covariates. Biostatistics 2004;5:381-98.

24 Miglioretti DL, Heagerty, PJ. Marginal modeling of nonnested multilevel data using standard software. Am J Epidemiol 2007;165:453-63.

Accepted: 24 April 2012

\section{Cite this as: BMJ 2012;344:e3782}

This is an open-access article distributed under the terms of the Creative Commons Attribution Non-commercial License, which permits use, distribution, and reproduction in any medium, provided the original work is properly cited, the use is non commercial and is otherwise in compliance with the license. See: http://creativecommons.org/licenses/by$\mathrm{nc} / 2.0 /$ and http://creativecommons.org/licenses/by-nc/2.0/legalcode. 


\section{What is already known on this topic}

High altitude mountaineering is an extremely dangerous and increasingly popular activity, with mortality rates exceeding those of almost any other recreational activity

Owing to a trend towards the commercialisation of Himalayan mountaineering, relatively inexperienced climbers are mentored by professional guides to climb peaks they would not otherwise have been experienced enough to climb on their own

Injury rates of high altitude mountaineering have fallen over the past several decades

\section{What this study adds}

Commercial Himalayan expeditions are not more dangerous than traditional expeditions and could in fact be safer

Climbers with considerable previous climbing experience in the Nepalese Himalayas are as likely to die as climbers on their first expedition; experience in the region is not associated with a survival benefit

\section{Tables}

\begin{tabular}{|c|c|c|c|c|}
\hline \multirow[b]{2}{*}{ Variable } & \multirow[b]{2}{*}{ Unique climbers } & \multicolumn{3}{|c|}{ Climbs } \\
\hline & & $<8000 \mathrm{~m}$ & $\geq 8000 \mathrm{~m}$ & Total \\
\hline \multicolumn{5}{|c|}{ Sex of climber } \\
\hline Male & $21555(89.8)$ & $14157(89.9)$ & $21293(91.4)$ & $35450(90.8)$ \\
\hline Female & $2439(10.2)$ & $1585(10.1)$ & $2002(8.6)$ & $3587(9.2)$ \\
\hline Unknown & 1 & 1 & 0 & 1 \\
\hline \multicolumn{5}{|c|}{ Age of climber (years) } \\
\hline$\leq 19$ & $161(0.7)$ & $103(0.7)$ & $87(0.4)$ & $190(0.5)$ \\
\hline $20-29$ & $7378(30.8)$ & 4619 (29.3) & $5126(22.0)$ & $9745(25.0)$ \\
\hline $30-39$ & 8945 (37.3) & $5563(35.3)$ & $9550(41.0)$ & $15113(38.7)$ \\
\hline $40-49$ & $4468(18.6)$ & $3130(19.9)$ & $5697(24.5)$ & $8827(22.6)$ \\
\hline $50-59$ & $1705(7.1)$ & $1357(8.6)$ & $1962(8.4)$ & $3319(8.5)$ \\
\hline$\geq 60$ & $492(2.1)$ & $427(2.7)$ & $485(2.1)$ & $912(2.3)$ \\
\hline Unknown & $846(3.5)$ & $544(3.5)$ & $388(1.7)$ & $932(2.4)$ \\
\hline \multicolumn{5}{|c|}{ Expedition numbert } \\
\hline 1 & $16976(70.8)$ & $11055(70.2)$ & $12365(53.1)$ & $23420(60.0)$ \\
\hline $2-4$ & $5817(24.2)$ & $3628(23.1)$ & 7735 (33.2) & $11363(29.1)$ \\
\hline $5-9$ & $921(3.8)$ & $752(4.8)$ & $2246(9.6)$ & $2998(7.7)$ \\
\hline$\geq 10$ & $249(1.0)$ & $291(1.9)$ & $934(4.0)$ & $1225(3.1)$ \\
\hline Unknown & $32(0.1)$ & $17(0.1)$ & $15(0.1)$ & $32(0.1)$ \\
\hline Total & 23995 & 15743 & 23295 & 39038 \\
\hline
\end{tabular}

*Age at Himalayan debut for climbers; age at time of expedition for climbs.

†Number of career expeditions for climbers; sequence of the current expedition for climbs. 


\begin{tabular}{|c|c|c|c|c|}
\hline Variable & Traditional & Commercial & Total & \\
\hline \multicolumn{5}{|l|}{ Sex of climber } \\
\hline Male & 28457 (91.6) & $6993(87.9)$ & $35450(90.8)$ & \\
\hline Female & $2625(8.5)$ & $962(12.1)$ & $3587(9.2)$ & \\
\hline Unknown & 1 & 0 & 1 & \\
\hline \multicolumn{5}{|l|}{ Age of climber (years) } \\
\hline$\leq 19$ & $156(0.5)$ & $34(0.4)$ & $190(0.5)$ & \\
\hline $20-29$ & $8710(28.0)$ & $1035(13.0)$ & $9745(25.0)$ & \\
\hline $30-39$ & $12280(39.5)$ & $2833(35.6)$ & $15113(38.7)$ & \\
\hline $40-49$ & $6355(20.5)$ & $2472(31.1)$ & $8827(22.6)$ & \\
\hline $50-59$ & $2136(6.9)$ & $1183(14.9)$ & $3319(8.5)$ & \\
\hline$\geq 60$ & $578(1.9)$ & $334(4.2)$ & $912(2.3)$ & \\
\hline Unknown & $868(2.8)$ & $64(0.8)$ & $932(2.4)$ & \\
\hline \multicolumn{5}{|l|}{ Expedition number } \\
\hline 1 & $18796(60.5)$ & $4624(58.1)$ & $23420(60.0)$ & \\
\hline $2-4$ & $9033(29.1)$ & $2330(29.3)$ & $11363(29.1)$ & \\
\hline $5-9$ & $2356(7.6)$ & $642(8.1)$ & $2998(7.7)$ & \\
\hline$\geq 10$ & $872(2.8)$ & $353(4.4)$ & $1225(3.1)$ & \\
\hline Unknown & $26(0.1)$ & $6(0.1)$ & $32(0.1)$ & \\
\hline \multicolumn{5}{|l|}{ Route } \\
\hline Non-standard & $15793(50.8)$ & $1563(19.7)$ & $17356(44.5)$ & \\
\hline Standard & $15290(49.2)$ & $6392(80.4)$ & $21682(55.5)$ & \\
\hline \multicolumn{5}{|l|}{ Season } \\
\hline Spring & $14139(45.5)$ & $3688(46.4)$ & $17827(45.7)$ & \\
\hline Summer & $354(1.1)$ & $24(0.3)$ & $378(1.0)$ & \\
\hline Autumn & $15160(48.8)$ & $4131(51.9)$ & $19291(49.4)$ & \\
\hline Winter & $1430(4.6)$ & $112(1.4)$ & $1542(4.0)$ & \\
\hline \multicolumn{5}{|l|}{ Altitude of peak (m) } \\
\hline$\leq 7000$ & $5641(18.2)$ & $1731(21.8)$ & $7372(18.9)$ & \\
\hline 7000-7999 & 7210 (23.2) & $1161(14.6)$ & $8371(21.4)$ & \\
\hline$\geq 8000$ & $18232(58.7)$ & $5063(63.7)$ & $23295(59.7)$ & \\
\hline \multicolumn{5}{|l|}{$8000 \mathrm{~m} \mathrm{peaks}^{\star}$} \\
\hline Annapurna I & $1144(6.3)$ & $55(1.1)$ & $1199(5.2)$ & \\
\hline Cho Oyu & $3632(19.9)$ & $2055(40.6)$ & $5687(24.4)$ & \\
\hline Dhaulagiri I & $1503(8.2)$ & $164(3.2)$ & $1667(7.2)$ & \\
\hline Everest & $7004(38.4)$ & $2331(46.0)$ & $9335(40.1)$ & \\
\hline Kangchenjunga & $1005(5.5)$ & $28(0.6)$ & $1033(4.4)$ & \\
\hline Lhotse & $1191(6.5)$ & $132(2.6)$ & $1323(5.7)$ & \\
\hline Makalu & $1368(7.5)$ & $58(1.2)$ & $1426(6.1)$ & \\
\hline Manaslu & $1385(7.6)$ & $240(4.7)$ & $1625(7.0)$ & \\
\hline Success & $8712(28.0)$ & $3534(44.4)$ & $12246(31.4)$ & \\
\hline Death & $524(1.7)$ & $55(0.7)$ & $579(1.5)$ & \\
\hline \multicolumn{5}{|l|}{ Mechanism of death $\dagger$} \\
\hline Acute mountain sickness & $28(5.3)$ & $5(9.1)$ & $33(5.7)$ & \\
\hline Exposure & $49(9.4)$ & $8(14.5)$ & $57(9.8)$ & \\
\hline Fall & $216(41.2)$ & $29(52.7)$ & $245(42.3)$ & \\
\hline Crevasse & $13(2.5)$ & $1(1.8)$ & $14(2.4)$ & \\
\hline Avalanche & $162(30.9)$ & $3(5.5)$ & $165(28.5)$ & \\
\hline Falling debris & $11(2.1)$ & $1(1.8)$ & $12(2.1)$ & \\
\hline
\end{tabular}


Table 2 (continued)

\begin{tabular}{lccc} 
Variable & Traditional & Commercial & Total \\
Other & $20(3.8)$ & $6(10.9)$ & $26(4.5)$ \\
\hline Unknown & $25(4.8)$ & $2(3.6)$ & $27(4.7)$ \\
\hline
\end{tabular}

*Percentages of $8000 \mathrm{~m}$ peak climbs only.

†Percentages of total deaths for traditional or commercial expeditions. 


\begin{tabular}{|c|c|c|c|c|c|c|c|c|c|c|c|c|c|c|c|c|c|}
\hline \multicolumn{2}{|c|}{$\begin{array}{c}\text { Acute } \\
\text { mountain } \\
\text { sickness }\end{array}$} & \multicolumn{2}{|c|}{ Exposure } & \multicolumn{2}{|c|}{ Fall } & \multicolumn{2}{|c|}{ Crevasse } & \multicolumn{2}{|c|}{ Avalanche } & \multicolumn{2}{|c|}{$\begin{array}{l}\text { Falling } \\
\text { debris }\end{array}$} & \multicolumn{2}{|c|}{ Other } & \multicolumn{2}{|c|}{ Unknown } & \multicolumn{2}{|c|}{ Total } \\
\hline $\mathbf{T}$ & C & $\mathbf{T}$ & C & $\mathbf{T}$ & c & $\mathbf{T}$ & C & $\mathbf{T}$ & C & $\mathbf{T}$ & c & $\mathbf{T}$ & C & $\mathbf{T}$ & c & $\mathbf{T}$ & c \\
\hline \multicolumn{18}{|c|}{ At base camp or lower altitude } \\
\hline $2(0.4)$ & 0 & $1(0.2)$ & 0 & $3(0.6)$ & 0 & 0 & 0 & $7(1.3)$ & 0 & 0 & 0 & $\begin{array}{c}4 \\
(0.8) \\
\end{array}$ & $\begin{array}{c}2 \\
(3.6) \\
\end{array}$ & 0 & 0 & $\begin{array}{c}17 \\
(3.2) \\
\end{array}$ & $2(3.6)$ \\
\hline \multicolumn{18}{|c|}{ Route preparation } \\
\hline $\begin{array}{c}10 \\
(1.9) \\
\end{array}$ & 0 & $\begin{array}{c}17 \\
(3.2) \\
\end{array}$ & 0 & $\begin{array}{c}66 \\
(12.6) \\
\end{array}$ & $\begin{array}{c}3 \\
(5.5) \\
\end{array}$ & $\begin{array}{c}5 \\
(1.0) \\
\end{array}$ & $\begin{array}{c}1 \\
(1.8) \\
\end{array}$ & $\begin{array}{c}126 \\
(24.1) \\
\end{array}$ & $\begin{array}{c}2 \\
(3.6) \\
\end{array}$ & $\begin{array}{c}7 \\
(1.3) \\
\end{array}$ & 0 & $\begin{array}{c}8 \\
(1.5) \\
\end{array}$ & 0 & $\begin{array}{c}5 \\
(1.0) \\
\end{array}$ & $\begin{array}{c}1 \\
(1.8) \\
\end{array}$ & $\begin{array}{c}244 \\
(46.6) \\
\end{array}$ & $\begin{array}{c}7 \\
(12.7) \\
\end{array}$ \\
\hline \multicolumn{18}{|c|}{ Ascending $^{*}$} \\
\hline 0 & 0 & $2(0.4)$ & 0 & $\begin{array}{c}38 \\
(7.3) \\
\end{array}$ & 0 & $\begin{array}{c}2 \\
(0.4) \\
\end{array}$ & 0 & $\begin{array}{c}12 \\
(2.3) \\
\end{array}$ & $\begin{array}{c}1 \\
(1.8) \\
\end{array}$ & 0 & 0 & 0 & $\begin{array}{c}1 \\
(1.8) \\
\end{array}$ & $\begin{array}{c}10 \\
(1.9) \\
\end{array}$ & 0 & $\begin{array}{c}64 \\
(12.2) \\
\end{array}$ & $2(3.6)$ \\
\hline \multicolumn{18}{|c|}{ Descending $^{*}$} \\
\hline $\begin{array}{c}15 \\
(2.9) \\
\end{array}$ & $\begin{array}{c}5 \\
(9.1) \\
\end{array}$ & $\begin{array}{c}29 \\
(5.5) \\
\end{array}$ & $\begin{array}{c}8 \\
(14.6) \\
\end{array}$ & $\begin{array}{c}101 \\
(19.3) \\
\end{array}$ & $\begin{array}{c}24 \\
(43.6) \\
\end{array}$ & $\begin{array}{c}3 \\
(0.6) \\
\end{array}$ & 0 & $4(0.8)$ & 0 & $\begin{array}{c}2 \\
(0.4) \\
\end{array}$ & $\begin{array}{c}1 \\
(1.8) \\
\end{array}$ & $\begin{array}{c}7 \\
(1.3) \\
\end{array}$ & $\begin{array}{c}2 \\
(3.6) \\
\end{array}$ & $\begin{array}{c}10 \\
(1.9) \\
\end{array}$ & $\begin{array}{c}1 \\
(1.8) \\
\end{array}$ & $\begin{array}{c}171 \\
(32.6) \\
\end{array}$ & $\begin{array}{c}41 \\
(74.5) \\
\end{array}$ \\
\hline \multicolumn{18}{|c|}{ Evacuation } \\
\hline 0 & 0 & 0 & 0 & $8(1.5)$ & $\begin{array}{c}2 \\
(3.6) \\
\end{array}$ & $\begin{array}{c}3 \\
(0.6) \\
\end{array}$ & 0 & $\begin{array}{c}13 \\
(2.5) \\
\end{array}$ & 0 & $\begin{array}{c}2 \\
(0.4) \\
\end{array}$ & 0 & $\begin{array}{c}1 \\
(0.2) \\
\end{array}$ & $\begin{array}{c}1 \\
(1.8) \\
\end{array}$ & 0 & 0 & $\begin{array}{c}27 \\
(5.2) \\
\end{array}$ & $3(5.5)$ \\
\hline \multicolumn{18}{|c|}{ Other or unknown } \\
\hline $1(0.2)$ & 0 & 0 & 0 & 0 & 0 & 0 & 0 & 0 & 0 & 0 & 0 & 0 & 0 & 0 & 0 & $1(0.2)$ & 0 \\
\hline \multicolumn{18}{|l|}{ Total } \\
\hline $\begin{array}{c}28 \\
(5.3)\end{array}$ & $\begin{array}{c}5 \\
(9.1)\end{array}$ & $\begin{array}{c}49 \\
(9.4) \\
\end{array}$ & $\begin{array}{c}8 \\
(14.6)\end{array}$ & $\begin{array}{c}216 \\
(41.2)\end{array}$ & $\begin{array}{c}29 \\
(52.7)\end{array}$ & $\begin{array}{c}13 \\
(2.5)\end{array}$ & $\begin{array}{c}1 \\
(1.8)\end{array}$ & $\begin{array}{c}162 \\
(30.9)\end{array}$ & $\begin{array}{c}3 \\
(5.5)\end{array}$ & $\begin{array}{c}11 \\
(2.1)\end{array}$ & $\begin{array}{c}1 \\
(1.8)\end{array}$ & $\begin{array}{c}20 \\
(3.8)\end{array}$ & $\begin{array}{c}6 \\
(10.9)\end{array}$ & $\begin{array}{c}25 \\
(4.8)\end{array}$ & $\begin{array}{c}2 \\
(3.6)\end{array}$ & $\begin{array}{c}524 \\
(100.0)\end{array}$ & $\begin{array}{c}55 \\
(100.0) \\
\end{array}$ \\
\hline
\end{tabular}




\begin{tabular}{|c|c|c|c|c|c|c|}
\hline Variable & First climb & Second to fourth climb & Fifth to ninth climb & 10th climb onwards & Unknown & Total \\
\hline \multicolumn{7}{|l|}{ Sex of climber } \\
\hline Male & $21011(89.7)$ & 10401 (91.5) & $2831(94.4)$ & $1176(96.0)$ & 31 & $35450(90.8)$ \\
\hline Female & 2409 (10.3) & $962(8.5)$ & $167(5.6)$ & $49(4.0)$ & 0 & 3587 (9.2) \\
\hline Unknown & 0 & 0 & 0 & 0 & 1 & 1 \\
\hline \multicolumn{7}{|l|}{ Age of climber (years) } \\
\hline$\leq 19$ & $157(0.7)$ & $29(0.3)$ & $4(0.1)$ & 0 & 0 & $190(0.5)$ \\
\hline $20-29$ & 7235 (30.9) & $2225(19.6)$ & $262(8.7)$ & $23(1.9)$ & 0 & $9745(25.0)$ \\
\hline $30-39$ & $8752(37.4)$ & $4823(42.4)$ & $1186(39.6)$ & $352(28.7)$ & 0 & $15113(38.7)$ \\
\hline $40-49$ & $4365(18.6)$ & $2891(25.4)$ & $1062(35.4)$ & $509(41.6)$ & 0 & $8827(22.6)$ \\
\hline $50-59$ & $1653(7.1)$ & $1020(9.0)$ & $380(12.7)$ & $266(21.7)$ & 0 & $3319(8.5)$ \\
\hline$\geq 60$ & $467(2.0)$ & $285(2.5)$ & $94(3.1)$ & $66(5.4)$ & 0 & $912(2.3)$ \\
\hline Unknown & $791(3.4)$ & $90(0.8)$ & $10(0.3)$ & $9(0.7)$ & 32 & $932(2.4)$ \\
\hline \multicolumn{7}{|l|}{ Season } \\
\hline Spring & $9553(40.8)$ & 5849 (51.5) & $1654(55.2)$ & $754(61.6)$ & 17 & $17827(45.7)$ \\
\hline Summer & $192(0.8)$ & $103(0.9)$ & $52(1.7)$ & $31(2.5)$ & 0 & $378(1.0)$ \\
\hline Autumn & 12788 (54.6) & $4938(43.5)$ & $1161(38.7)$ & $398(32.5)$ & 6 & $19291(49.4)$ \\
\hline Winter & $887(3.8)$ & $473(4.2)$ & $131(4.4)$ & $42(3.4)$ & 9 & $1542(4.0)$ \\
\hline \multicolumn{7}{|l|}{ Altitude of peak (m) } \\
\hline$\leq 7000$ & $5078(21.7)$ & $1687(14.9)$ & $408(13.6)$ & $183(14.9)$ & 16 & $7372(18.9)$ \\
\hline 7000-7999 & 5977 (25.5) & $1941(17.1)$ & 344 (11.5) & $108(8.8)$ & 1 & $8371(21.4)$ \\
\hline$\geq 8000$ & 12365 (52.8) & $7735(68.1)$ & $2246(74.9)$ & $934(76.2)$ & 15 & 23295 (59.7) \\
\hline \multicolumn{7}{|l|}{$8000 \mathrm{~m}$ peaks ${ }^{*}$} \\
\hline Annapurna I & $648(5.2)$ & $350(4.5)$ & $117(5.2)$ & $84(9.0)$ & 0 & $1199(5.2)$ \\
\hline Cho Oyu & $3813(30.8)$ & $1404(18.2)$ & $345(15.4)$ & $125(13.4)$ & 0 & $5687(24.4)$ \\
\hline Dhaulagiri I & 899 (7.3) & $544(7.0)$ & $166(7.4)$ & $58(6.2)$ & 0 & $1667(7.2)$ \\
\hline Everest & $4468(36.1)$ & $3510(45.4)$ & $953(42.4)$ & $389(41.7)$ & 15 & $9335(40.1)$ \\
\hline Kangchenjunga & $479(3.9)$ & $383(5.0)$ & $116(5.2)$ & $55(5.9)$ & 0 & $1033(4.4)$ \\
\hline Lhotse & $539(4.4)$ & 507 (6.6) & $185(8.2)$ & $92(9.9)$ & 0 & $1323(5.7)$ \\
\hline Makalu & $663(5.4)$ & $504(6.5)$ & $195(8.7)$ & $64(6.9)$ & 0 & $1426(6.1)$ \\
\hline Manaslu & $856(6.9)$ & $533(6.9)$ & $169(7.5)$ & $67(7.2)$ & 0 & $1625(7.0)$ \\
\hline \multicolumn{7}{|l|}{ Status } \\
\hline Traditional & 18796 (80.3) & $9033(79.5)$ & $2356(78.6)$ & $872(71.2)$ & 26 & $31083(79.6)$ \\
\hline Commercial & $4624(19.7)$ & $2330(20.5)$ & $642(21.4)$ & $353(28.8)$ & 6 & $7955(20.4)$ \\
\hline \multicolumn{7}{|l|}{ Route } \\
\hline Non-standard & 11208 (47.9) & $4730(41.6)$ & $1041(34.7)$ & $360(29.4)$ & 17 & $17356(44.5)$ \\
\hline Standard & $12212(52.1)$ & $6633(58.4)$ & $1957(65.3)$ & $865(70.6)$ & 15 & $21682(55.5)$ \\
\hline \multicolumn{7}{|l|}{ Summit success } \\
\hline No & $17172(73.3)$ & $7308(64.3)$ & $1689(56.3)$ & $610(49.8)$ & 13 & $26792(68.6)$ \\
\hline Yes & $6248(26.7)$ & 4055 (35.7) & $1309(43.7)$ & $615(50.2)$ & 19 & $12246(31.4)$ \\
\hline Death & $348(1.5)$ & $166(1.5)$ & $49(1.6)$ & $16(1.3)$ & 0 & $579(1.5)$ \\
\hline \multicolumn{7}{|l|}{ Mechanism of death } \\
\hline Acute mountain sickness & $12(3.5)$ & $16(9.6)$ & $4(8.2)$ & $1(6.3)$ & 0 & $33(5.7)$ \\
\hline Exposure & $29(0.1)$ & $20(0.2)$ & $7(0.2)$ & $1(0.1)$ & 0 & $57(9.8)$ \\
\hline Fall & $151(43.4)$ & $70(42.2)$ & $19(38.8)$ & $5(31.3)$ & 0 & $245(42.3)$ \\
\hline Crevasse & $6(1.7)$ & $6(3.6)$ & $1(2.0)$ & $1(6.3)$ & 0 & $14(2.4)$ \\
\hline Avalanche & $116(33.3)$ & $35(21.1)$ & $11(22.5)$ & $3(18.8)$ & 0 & $165(28.5)$ \\
\hline Falling debris & $6(1.7)$ & $4(2.4)$ & $1(2.0)$ & $1(6.3)$ & 0 & $12(2.1)$ \\
\hline Other & $16(4.6)$ & $8(4.8)$ & $1(2.0)$ & $1(6.3)$ & 0 & $26(4.5)$ \\
\hline
\end{tabular}




\section{Table 4 (continued)}

Variable First climb Second to fourth climb Fifth to ninth climb 10th climb onwards Unknown Total

\begin{tabular}{lcccccc} 
Unknown & $12(3.5)$ & $7(4.2)$ & $5(10.2)$ & $3(18.8)$ & 0 & $27(4.7)$ \\
\hline Total & 23420 & 11363 & 2998 & 1225 & 32 & 39038 \\
\hline
\end{tabular}

*Percentages relative to other $8000 \mathrm{~m}$ climbs only (23 295 total). 


\begin{tabular}{|c|c|c|c|c|c|}
\hline Variable & 1970s & 1980s & $1990 \mathrm{~s}$ & $2000 \mathrm{~s}$ & Total \\
\hline \multicolumn{6}{|l|}{ Sex of climber } \\
\hline Male & $2940(95.5)$ & 8008 (93.4) & 10237 & 13558 & $34743(90.9)$ \\
\hline Female & $139(4.5)$ & $566(6.6)$ & $1032(9.2)$ & $1762(11.5)$ & 3499 (9.2) \\
\hline Unknown & 1 & 0 & 0 & 0 & 1 \\
\hline \multicolumn{6}{|l|}{ Age of climber (years) } \\
\hline$\leq 19$ & $15(0.5)$ & $34(0.4)$ & $52(0.5)$ & $83(0.5)$ & $184(0.5)$ \\
\hline $20-29$ & $1298(42.1)$ & $3154(36.8)$ & $2631(23.4)$ & $2566(16.8)$ & 9649 (25.2) \\
\hline 30-39 & $1167(37.9)$ & $3491(40.7)$ & $4781(42.4)$ & $5430(35.4)$ & $14869(38.9)$ \\
\hline $40-49$ & $328(10.7)$ & $1179(13.8)$ & $2646(23.5)$ & $4403(28.8)$ & $8556(22.4)$ \\
\hline $50-59$ & $60(2.0)$ & $272(3.2)$ & $834(7.4)$ & 2026 (13.2) & $3192(8.4)$ \\
\hline$\geq 60$ & $11(0.4)$ & $39(0.5)$ & $128(1.1)$ & $688(4.5)$ & $866(2.3)$ \\
\hline Unknown & $201(6.5)$ & $405(4.7)$ & $197(1.8)$ & $124(0.8)$ & $927(2.4)$ \\
\hline \multicolumn{6}{|l|}{ Season } \\
\hline Spring & $1715(55.7)$ & 3229 (37.7) & $4392(39.0)$ & $7703(50.3)$ & $17039(44.6)$ \\
\hline Summer & 0 & $130(1.5)$ & $106(0.9)$ & $135(0.9)$ & $371(1.0)$ \\
\hline Autumn & $1336(43.4)$ & $425(51.6)$ & $6328(56.2)$ & $7202(47.0)$ & $19291(50.4)$ \\
\hline Winter & $29(1.0)$ & $790(9.2)$ & $443(3.9)$ & $280(1.8)$ & $1542(4.0)$ \\
\hline \multicolumn{6}{|l|}{ Altitude of peak (m) } \\
\hline$\leq 7000$ & $494(16.0)$ & 1415 (16.5) & $1957(17.4)$ & $3426(22.4)$ & $7292(19.1)$ \\
\hline 7000-7999 & $1219(39.6)$ & $2658(31.0)$ & $2174(19.3)$ & $2269(14.8)$ & $8320(21.8)$ \\
\hline$\geq 8000$ & 1367 (44.4) & $4501(52.5)$ & $7138(63.3)$ & $9625(62.8)$ & 22631 (59.2) \\
\hline \multicolumn{6}{|l|}{$8000 \mathrm{~m}_{\text {peaks }}{ }^{*}$} \\
\hline Annapurna I & $116(8.5)$ & $434(9.6)$ & $350(4.9)$ & $260(2.7)$ & $1160(5.1)$ \\
\hline Cho Oyu & $7(0.5)$ & $418(9.3)$ & 2065 (28.9) & 3139 (32.6) & 5629 (24.9) \\
\hline Dhaulagiri I & $176(12.9)$ & $408(9.1)$ & $614(8.6)$ & $433(4.5)$ & $1631(7.2)$ \\
\hline Everest & $541(39.6)$ & $1753(39.0)$ & $2637(36.9)$ & $4003(41.6)$ & 8934 (39.5) \\
\hline Kangchenjunga & $102(7.5)$ & $431(9.6)$ & 279 (3.9) & $218(2.3)$ & $1030(4.6)$ \\
\hline Lhotse & $113(8.3)$ & $341(7.6)$ & $259(3.63)$ & $571(5.9)$ & $1284(5.7)$ \\
\hline Makalu & $168(12.3)$ & $358(8.0)$ & $452(6.3)$ & $389(4.0)$ & $1367(6.0)$ \\
\hline Manaslu & $144(10.5)$ & $358(8.0)$ & $482(6.8)$ & $612(6.4)$ & $1596(7.1)$ \\
\hline \multicolumn{6}{|l|}{ Status } \\
\hline Traditional & 3014 (97.9) & 8167 (95.3) & $9012(80.0)$ & $10395(67.9)$ & $30588(80.0)$ \\
\hline Commercial & $66(2.1)$ & $407(4.8)$ & $2257(20.0)$ & 4925 (32.2) & $7655(20.0)$ \\
\hline \multicolumn{6}{|l|}{ Route } \\
\hline Non-standard & 2411 (78.3) & 6359 (74.2) & $4420(39.2)$ & $4019(26.2)$ & $17209(45)$ \\
\hline Standard & $669(21.7)$ & 2215 (25.8) & $6849(60.8)$ & $11301(73.8)$ & $21034(55)$ \\
\hline \multicolumn{6}{|l|}{ Summit success } \\
\hline No & 2417 (78.5) & 6741 (78.6) & $7982(70.8)$ & $9224(60.2)$ & 26364 (68.9) \\
\hline Yes & $663(21.5)$ & $1833(21.4)$ & $3287(29.2)$ & 6096 (39.8) & $11879(31.1)$ \\
\hline Death & $91(3.0)$ & $192(2.2)$ & $150(1.3)$ & $134(0.9)$ & 567 (1.5) \\
\hline \multicolumn{6}{|l|}{ Mechanism of death } \\
\hline Acute mountain sickness & $2(2.2)$ & $7(3.7)$ & $9(6.0)$ & $14(10.5)$ & $32(5.6)$ \\
\hline Exposure & $6(6.6)$ & $12(6.3)$ & $23(15.3)$ & $11(8.2)$ & $52(9.2)$ \\
\hline Fall & $34(37.4)$ & $87(45.3)$ & $71(47.3)$ & $51(38.1)$ & $243(42.9)$ \\
\hline Crevasse & $5(5.5)$ & $1(0.5)$ & $2(1.33)$ & $6(4.5)$ & $14(2.5)$ \\
\hline Avalanche & $38(41.8)$ & $69(35.9)$ & $26(17.3)$ & $31(23.1)$ & $164(28.9)$ \\
\hline Falling debris & $2(2.2)$ & $5(2.6)$ & $4(2.7)$ & $1(0.8)$ & $12(2.1)$ \\
\hline Other & $2(2.2)$ & $5(2.6)$ & $8(5.3)$ & $11(8.2)$ & $26(4.6)$ \\
\hline
\end{tabular}




\section{Table 5 (continued)}

\begin{tabular}{lccccc} 
Variable & $1970 s$ & $1980 s$ & $1990 s$ & $2000 s$ & Total \\
Unknown & $2(2.2)$ & $6(3.1)$ & $7(4.7)$ & $9(6.7)$ & $24(4.2)$ \\
\hline Total & 3080 & 8574 & 11269 & 15320 & 38243 \\
\hline
\end{tabular}

*Percentages relative to other $8000 \mathrm{~m}$ climbs only (23 295 total). 
Table 6 | Odds of death on $8000 \mathrm{~m}$ peaks estimated from a multivariate logistic regression model, by climb characteristics

\begin{tabular}{|c|c|c|}
\hline Variable & Odds ratio $(95 \% \mathrm{Cl})^{*}$ & Pt \\
\hline Expedition number $\ddagger$ & $1.00(0.96$ to 1.05$)$ & 0.904 \\
\hline Commercial status & & 0.100 \\
\hline Traditional & 1.00 & \\
\hline Commercial & $0.63(0.37$ to 1.09$)$ & \\
\hline Route & & 0.142 \\
\hline Non-standard & 1.00 & \\
\hline Standard & $0.74(0.49$ to 1.11$)$ & \\
\hline Peak & & $<0.001$ \\
\hline Annapurna I & 1.00 & \\
\hline Cho Oyu & 0.17 (0.08 to 0.36$)$ & \\
\hline Dhaulagiri I & $0.73(0.37$ to 1.44$)$ & \\
\hline Everest & $0.42(0.25$ to 0.73$)$ & \\
\hline Kangchenjunga & 0.55 (0.24 to 1.22$)$ & \\
\hline Lhotse & $0.42(0.18$ to 1.00$)$ & \\
\hline Makalu & $0.43(0.20$ to 0.90$)$ & \\
\hline Manaslu & $0.84(0.43$ to 1.64$)$ & \\
\hline Age of climber (decade of life) & 1.01 (0.99 to1.03) & 0.279 \\
\hline Season & & 0.910 \\
\hline Spring & 1.00 & \\
\hline Summer & $0.36(0.02$ to 6.00$)$ & \\
\hline Autumn & 0.98 (0.66 to 1.44$)$ & \\
\hline Winter & 1.05 (0.48 to 2.28$)$ & \\
\hline Sex of climber & & 0.995 \\
\hline Male & 1.00 & \\
\hline Female & 1.00 (0.56 to 1.79$)$ & \\
\hline Summit success & & 0.036 \\
\hline No & 1.00 & \\
\hline Yes & $1.50(1.03$ to 2.19$)$ & \\
\hline Year of expedition & 0.98 (0.96 to 0.99$)$ & 0.011 \\
\hline
\end{tabular}

*Standard errors adjusted for clustering on two population averaged models, using method described by Miglioretti and Heagerty. ${ }^{23,24}$ †Represents an omnibus hypothesis for each individual variable.

$\ddagger$ Credit given for all climbs to constituent peaks, including those with altitude $<8000 \mathrm{~m}$. 
Table 7| Summary of unadjusted mortality, by climb characteristics

\section{Variable No (\%) of deaths No of climbs}

Expedition number

\begin{tabular}{lcc}
\hline 1 & $348(1.5)$ & 23420 \\
\hline $2-4$ & $166(1.5)$ & 11363 \\
\hline $5-9$ & $49(1.6)$ & 2998 \\
\hline$\geq 10$ & $16(1.5)$ & 1225 \\
\hline Unknown & 0 & 32 \\
\hline
\end{tabular}

Commercial status

\begin{tabular}{lcc}
\hline Traditional & $524(1.7)$ & 31083 \\
\hline Commercial & $55(0.7)$ & 7955 \\
\hline
\end{tabular}

Route

\begin{tabular}{lll}
\hline Non-standard & $330(1.9)$ & 17356 \\
\hline Standard & $249(1.2)$ & 21682 \\
\hline
\end{tabular}

Peak

\begin{tabular}{lcc}
\hline Annapurna I & $48(4.0)$ & 1199 \\
\hline Cho Oyu & $29(0.5)$ & 5687 \\
\hline Dhaulagiri I & $45(2.7)$ & 1667 \\
\hline Everest & $136(1.5)$ & 9335 \\
\hline Kangchenjunga & $29(2.8)$ & 1033 \\
\hline Lhotse & $22(1.7)$ & 1323 \\
\hline Makalu & $24(1.7)$ & 1426 \\
\hline Manaslu & $47(2.9)$ & 1625 \\
\hline Altitude of peak (m) & & \\
\hline$\geq 8000$ & $380(1.6)$ & 23295 \\
\hline $7000-7999$ & $145(1.7)$ & 8371 \\
\hline$\leq 6999$ & $54(0.7)$ & 7372 \\
\hline
\end{tabular}

Age of climber (years)

\begin{tabular}{lcc}
\hline$\leq 19$ & $3(1.6)$ & 190 \\
\hline $20-29$ & $164(1.7)$ & 9745 \\
\hline $30-39$ & $237(1.6)$ & 15113 \\
\hline $40-49$ & $103(1.2)$ & 8827 \\
\hline $50-59$ & $34(1.0)$ & 3319 \\
\hline$\geq 60$ & $10(1.1)$ & 912 \\
\hline Unknown & $28(3.0)$ & 932 \\
\hline Spring & & \\
\hline Summer & $275(1.5)$ & 17827 \\
\hline Autumn & $273(1.4)$ & 19291 \\
\hline Winter & $30(2.0)$ & 1542 \\
\hline Sex of climber & & \\
\hline Male & $545(1.5)$ & 35450 \\
\hline Female & $34(1.0)$ & 3587 \\
\hline Unknown & 0 & 12246 \\
\hline Summit success & $1915(1.6)$ & 3080 \\
\hline No & $194.0)$ & 8574 \\
\hline Yes & & \\
\hline Decade of climb & & $12.2)$ \\
\hline $1970 s$ & & \\
\hline $1980 s$ & & \\
\hline
\end{tabular}




\section{Table 7 (continued)}

Variable No (\%) of deaths No of climbs

\begin{tabular}{lll}
$1990 \mathrm{~s}$ & $150(1.3)$ & 11269 \\
\hline $2000 \mathrm{~s}$ & $134(0.9)$ & 15320 \\
\hline
\end{tabular}




\section{Figures}

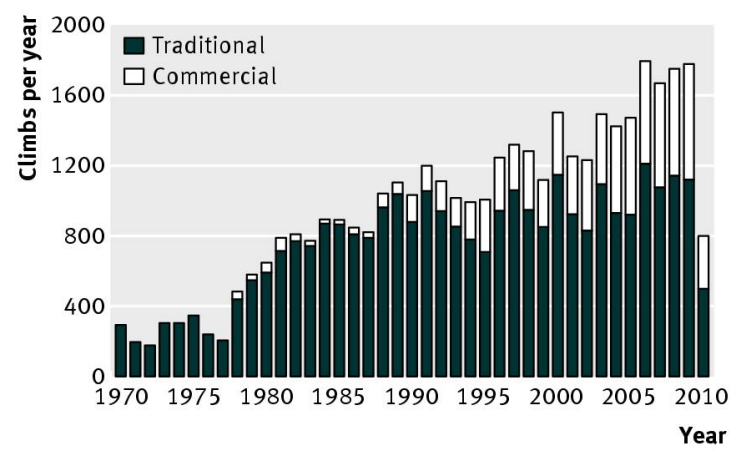

Fig 1 Annual individual climbs in the Nepalese Himalayas by commercial status, 1970-2010. Excludes climbs by high altitude porters. Data for 2010 were incomplete because they included the climbing season in spring only

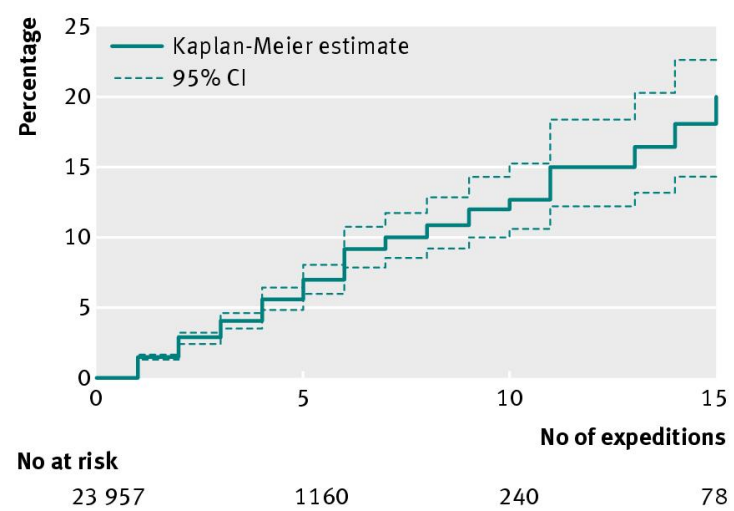

Fig 2 Cumulative mortality (\%) for a hypothetical Himalayan climbing career. X axis represents expedition time rather than calendar time 